\title{
BLENDING ONLINE LANGUAGE LABORATORY INTO INDONESIAN EFL LISTENING CLASSROOM
}

\author{
Arzal $^{1}$ \\ Zulkifli Tanipu ${ }^{2}$ \\ Department of English Language Education, Faculty of Arts and Humanities \\ State University of Gorontalo, Indonesia \\ 1arzal_m@yahoo.com \\ 2joe_selebes@yahoo.co.id
}

\begin{abstract}
Integrating Information Communication and Technology (ICT) into English as Foreign Language (EFL) classrooms is believed to enhance teaching and learning. This study promotes the use of online language laboratory into Indonesian EFL listening classroom. Using a mixed approach of qualitative and quantitative principles, this study examined 23 Indonesian learners of English at the State University of Gorontalo, Indonesia to see whether the use of online language laboratory can significantly increase the students' listening skills. In this experimental study, the participants' condition and achievement in the pre- and post test were compared. The result showed that there is a significant difference between listening score on the modified TOEIC-like test. The findings suggest that, it is beneficial for teachers of English to be aware of the effectiveness, flexibility, richness, and the other advantages of using online language laboratory in EFL especially listening classroom.
\end{abstract}

Keywords: teaching listening, blending technologies, online language laboratories.

\section{Introduction}

Over the past few decades, like any other ASEAN nations, Indonesia has been experiencing multiple educational reforms, including school curriculum and pedagogies in language teaching and learning. These reforms were due to the efforts to improve the output of teaching and learning in order to compete in the global context. Indonesia, through its ministry of Education, has seriously responded the growing needs to foster and strengthen English communication skills of the students (Kemendikbud, 2013).

English has become increasingly important as a foreign language taught in Indonesia. It is a compulsory subject to be taught for three years at Junior High Schools and for three years in Senior High Schools. English also has been taught in Elementary Schools as an elective subject since the implementation of the 1994 Curriculum. 
Other efforts have also been made to improve EFL teachers' language proficiency. Every year a number of teachers needs to sit for various English proficiency tests for academic purposes or for general purposes. Test of English as a Foreign Language (TOEFL), for example, is required for teachers who intend to pursue further study either in the non-English speaking countries or in English speaking countries.

To some extent these educational efforts have shown a slightly fruitful result. According to Education First Index (2013), the rank of Indonesia for English proficiency Index has significantly improved from 34 out of 54 in 2011 (Very Low Proficiency category) to 25 out of 54 countries in 2013 ("Moderate proficiency" category) (Education First, 2013). However, some studies have indicated that despite pedagogical changes, student results have not significantly improved and there is evidence of the unsatisfactory results and the lack of development of students' English communicative skills (Education First, 2013; Prihatin, 2012).

The setting of this study is one of the new Indonesian provinces of Gorontalo, situated in the Northern part of Sulawesi Island,the central part of Indonesia. Since its establishment in December 2000, with the population of more than 1 million people in 2011 (Badan Pusat Statistik, 2012), this 31st Indonesian province has been progressively developing its region by focusing on developing human resources through education as one of its three main development programs. Gorontalo province has increased its educational budget managed by the Provincial Office for Education to 88 billion IDR in 2013. The demand for English in this province has significantly increased due to the rapid change of economic development, socio-culture, education and information and technologies. The recruitment for the employees of government institutions, private organisation and companies, and universities, for example, require applicants with a minimum standard in English proficiency test such as TOEFL test and local English test. At higher education level, scholarships and fellowships are offered for overseas and domestic higher degrees or short programs with similar requirements. An example is youth exchange programs, such as Australian-Indonesian Youth Exchange program, Canadian-Indonesian Youth Exchange Program and ASEAN-Japanese Youth Exchange Program, have been seen as one of the great motivations for the young people to learn English.

Regardless its progressive development and its potential, challenges still exist. Evidence shows that the majority of students often leave schools and universities with little proficiency in English communication skills. As one of the state universities in Indonesia, the State University of Gorontalo through its Department of English Education has been progressively improving the quality of its teaching and learning, including infusing technology literacy as its graduate basic competence (Vision Statement of Department of English, 2012).

Since technology has revolutionised the society in the 20th and 21st century, Information and Communication Technologies (ICT) has played an important role and become powerful tools for education and development. It has created exceptional learning opportunities for learners in all aspects of their personal and academic life. Recently, a growing number of researchers have published studies that provide substantial evidence that integrating technology into educational 
programs provides students with supplementary tools that can enhance learning (Garrett,1991; Hackbarth,1996; Kolb, 2008; Pusack \& Otto, 1997). ICT also supports students in exploring and articulating thoughts, knowledge construction and theory building (Scardamalia \& Bereiter, 1991), and collaboration, negotiation of meanings, reflection on meaningful learning through accessing authentic information and immersing themselves in complex and contextualised learning situations (Meunier,1994; Urtel, 2008; Wilcox \& Wojnar, 2000).

With the advancement of ICT, especially with the Internet/WWW technology, one of the utilisation of technology in teaching and learning process is online language laboratory. Online language laboratory is one of the options that teachers can use to promote students' autonomy in learning as well increase students' language proficiency (Sharma \& Barrett, 2007). Online language laboratory can allow students to work at their own pace through self-paced learning modules. On-line laboratory also can provide students the option to select learning materials based on their level of knowledge and particularly their interest. Flexibility to join discussions at any hour and visitising classmates and teachers in chat rooms is one of the adventages. Learning through online language laboratory can accommodate different learning styles and facilitate learning through a variety of activities. It develops knowledge of the internet and computers skills that will help learners throughout their lives and careers. Successfully completing online or computerbased courses builds self-knowledge and self-confidence and encourages students to take responsibility for their learning. Learners can test out or skim over materials already mastered and concentrate efforts in mastering areas containing new information and/or skills.

Over the past few years, a blended learning, learning which combine a faceto-face and online mode, has been considered to benefit teaching and learning. According to Cambridge University ESOL (2010), within the boundaries established by their course, learners can study at their own pace at a time and place which suits them. Learners have a measure of assurance and motivation in the knowledge that they will be given the opportunity to try out what they have learned in a teacher-led face-to-face session. A strong benefit of blended learning, particularly with large groups, is that it offers a time-effective and personalised way of learning and practicing material. A large number of students can be challenging in the Indonesian context of teaching and learning. However, with the blended learning concept, materials and teaching delivery mode can be personalised and managed individually.

In addition, blended learning is intended to set the individual student at the centre of the teaching and learning experience. In this concept, learners are empowered and need to be guided in how to take responsibility for their own learning. Teachers can use the face-to-face lessons to address and provide guidance on specific issues and questions that the individual learner may have.

Blended learning denies the misconception of the use of blended learning can replace teachers. Blended learning is designed to offer students flexibility. It makes sense that blended learning should offer the opportunity for learners to access more of their course content independently and to work more autonomously. In higher education context, there are more opportunities for exploration and growth in the use of technology in language and teaching. The increase of student 
demands for more learning options may drive the growth of the use of technologies in this field.

\section{Purpose of the Study}

This study examined the impact of using on-line laboratory on students' listening skills, by investigating whether or not students' language proficiency can be improved when online language laboratory is blended into the classroom.

\section{Research Method}

\section{Participants}

The participants were 23 Indonesian EFL students, from the Department of English Language Education, Faculty of Arts and Humanities, State University of Gorontalo, Indonesia. They were in the second year and considered as the intermediate-level users of English as a foreign language. The participants were selected on the basis of purposiveness and availability.

\section{Data Collection}

This study used a mixed approach of quantitative and qualitative method. A quantitative method was used to examine whether there is a significant difference before and after the treatment based on the result of pre- and post-test in onegroup study design. Pre- and post-tests were used to measure knowledge gained in the 5-meeting online laboratory session in the treatment. Meanwhile, a qualitative method of interview was used to explore the students' experiences during the blended learning which includes their perception, experiences, feelings, bestpractices, and the lesson-learned about the use of online language laboratory.

For the pre-test, the participants were given an English proficiency test which contains listening testin order to determine their knowledge level before the treatment. The English proficiency test was a modified TOEIC-like test which is a semi-full version of TOEIC test. This is done due to the limited time and the nature of data needed for the study. TOEIC test scores provide accurate, reliable measurement of English proficiency - they can be compared regardless of where or when the test is administered. For example, last year's scores of a test taker in Japan can be compared with this year's scores of a test taker in Korea. Because test takers of any background can be compared fairly, companies can use the TOEIC tests to make the most informed decisions and build a more diverse workforce (ETS, 2012). The post-test questions were the same as the the pre-test.

The treatment given to the participants comprised 5 meetings using two online laboratories which blended online language laboratory into the listening class . These two websites require no login and password and it is free, so they can be accessed by all students. The first online language laboratory is www.esl-lab.com or 
we call it "Randall's ESL Cyber Listening Lab". This online lab is an online, multimedia listening website designed to help ESOL students improve their listening comprehension skills in English. According to the official website of this online language laboratory, it has also been used widely in the US by the hearing impaired with cochlear implants. It is reported that students and teachers from over 150 countries have visited the site since 1998. The Website is supported through contextual advertising related to topics on the site. The second online language laboratory used was www.elllo.org.

In each 50-minute semi-structured session of the treatment, the participants were assigned to do some online listening tasks with different topics every session. Some pre-listening activities had been done as part of the instruction on the website to introduce the topic. The participants listened to the recording and answered questions regarding the recording. The questions on these websites have a variety of forms such as a multiple choice and matching test. Participants could check their answer and check the score they got at the same time. They could repeat this listening exercise as many as they like to get a higher score.

The treatment consisted of two modes: blended learning in teaching and learning, followed by self-study. In the blended learning mode, online language learning was used as the main part of teaching and learning activities in the classroom. Students accessed the online language laboratory as stated on the lesson plan. For example, the students went to the particular link on the http://www.esllab.com and did some exercises based on the selected topic. Students then did some listening practices, and answered questions in the website. This is was followed by the self-study mode, whereby the students were given follow-up activities in the form of self-study assignments, completed in their own time.

After the completion of the 5-session treatment, a post-test which contained the same set of questions in the pre-test was given to the participants. A paired $\mathrm{t}$-test was used to measure whether there was a significant difference between the means of the pre-test and post-test to determine whether online laboratory sessions could significantly increase students' listening proficiency.

All the participants were interviewed to study their perception on the following: 1) the extent to which their listening skills had improved; 2) their lessons learned from the use of online language laboratory; 3)the areas of improvement, experiences of new learning circumstances, language aspects, and cultural exposure to the real context of English.

\section{Result and Discussion}

The students' proficiency test scores from the pre- and post test are shown in Tables 1 and 2. 
Table 1.

Descriptive statistics on listening scores for pre-and post-tests

\begin{tabular}{lccccc} 
& $\mathrm{N}$ & Minimum & Maximum & Mean & Std. Deviation \\
Pre-test & 23 & 65 & 75 & 68.22 & 3.133 \\
Post-test & 23 & 76 & 90 & 83.35 & 4.509 \\
\hline Valid N (listwise) & 23 & & & & \\
\hline
\end{tabular}

Table 2.

Paired samples statistics on listening pre and post test scores

\begin{tabular}{llrrrr}
\hline & & & & \multicolumn{2}{c}{ Std. Error } \\
Pair 1 & Mean & $\mathrm{N}$ & \multicolumn{2}{c}{ Std. Deviation } & \multicolumn{2}{c}{ Mean } \\
\cline { 2 - 7 } & listPre & 68.22 & 23 & 3.133 & .653 \\
\hline ListPost & 83.35 & 23 & 4.509 & .940 \\
\hline
\end{tabular}

The results show that there is a significant difference in the scores for pre-test listening $(M=68.22, S D=3.13)$ and post-test listening $(M=83.35, S D=4.50)$ conditions; $\mathrm{t}(22)=-22.13, \mathrm{p}<0.005$

\section{Students' perceptions of online language laboratory}

This study suggests that blending online language laboratory into the listening class improves students' listening skills, not only according to the result from the t-test but also from the interview. The interview shows that students had positive responses on how this online language laboratory had increased their listening proficiency. For example, one student pointed out how the difficulty in defining the main topic of the discussion was overcome:

It was a bit hard for me to get a main idea of the conversation. I always try and try to practice when I have my own time. I go online and repeat the recording on the website. Now I am good at knowing the idea of the simple talk. I am really happy for that. (Extract 1.2).

Students also found that it helps them to develop their skills in finding the details on the conversation.

At the first, I have to go back and forward to listening very carefully on what is being said by the people on the recordings, especially when you find questions about the particular information on the recording. Such as what time the speakers would meet each other. The good thing about learning 
from the website is that you can always repeat and click if you want it. (Extract 8.2)

The result of the interview shows that most students had positive learning experiences with the online language laboratory. The students reported that the online laboratory is absolutely beneficial for their English learning, especially for their listening skills improvement.

It was good to have listening materials or recordings on the websites where we can practice our listening comprehension. (Extract 6.5)

I like the listening exercises of esl-lab website where I can improve my language proficiency, especially listening. (Extract 10.5)

The online language laboratory also enabled students to develop their independent learning style.

The good thing with the online language laboratory is that I can visit and revisit as many as I like, and listen to the recording without waiting for other friends or waiting for your teacher's instruction. (Extract 1.2)

I always have my own time to study and repeat the lessons at home or when I have a cup of coffee at cafe with friends with the free wireless. It is very convenient. (Extract 6.2)

Independent learning style is considered to be the main key of blending online language laboratory into teaching and learning instruction. It gives more flexibility and opportunity for students to explore the rich source of learning on their own pace and time. The use of online language laboratories increased student engagement. One of the principles of blending online language laboratories into classroom instruction is to promote active participation in learning, keep students motivated and engaged.

The students stated that online language Laboratory improves their technological skills which they believe is one of the necessary skills for their academic success at university.

I, myself, like computer technology. Everyday, I try to do something interesting to learn with the technology. Learning with website, I feel I can improve my technological skill. (Extract 7.7).

I was excited with this teaching method, because I learn new things with the technology. I think, I will still need to study the new things related to the technology such as learning how to make a blog, or design my own website. (Extract 8.7)

This study also found that students felt that they obtained a great deal of exposure to the target language in the online language laboratory. Communicating with "real" native speakers of English directly from the online language laboratory, 
which may not be available in most conventional face-to-face classroom environments, is considered to be an important benefit and a bonus.

\section{Conclusion}

Integrating technologies into language and teaching is found to be an effective effort to enhance teaching and learning. Blending online language laboratory is one of the models to combine a face-to-face and online teaching and learning. This study found that the use of online language laboratory in the English listening classroom can significantly improve students' listening skills after five sessions. The students also had positive experiences on how language laboratory can enhance their listening skills development.

\section{References}

Badan Pusat Statistik. (2012). Kependudukan propinsi Gorontalo. BPS: Gorontalo Cambridge University ESOL. (2010). Blended learning FAQs. Retrieved July 5, 2012, from https://www.teachers.cambridgeesol.org/ts/digitalAssets/116069_ Blended_Learning_FAQs_Nov10.pdf

Education First, 2011. English Proficiency Index. URL http://www.efuk.co.uk/sitecore/_//media/efcom/epi/pdf/EF-EPI-2011.pdf

ETS. (2012). The TOEIC ${ }^{\circledR}$ Tests - the global standard for assessing English proficiency for business. Retrieved July 5, 2012, from https://www.ets.org/toeic/succeed

Garrett, N. (1991). Technology in the service of language learning: Trends and issues. The Modern Language Journal, 75 (1), 74-101.

Hackbarth, S. (1996). The educational technology handbook: A comprehensive guide: Process and products for learning. Englewood Cliffs, NJ: Educational Technology Publications.

Kemendikbud. (2013). Kurikulum 2013. Jakata: Kemendikbud.

Kolb, L. (2008). Toys to tools: Connecting cell phones to education. Washington: ISTE.

Meunier, L. E. (1994). Computer-assisted language instruction and cooperative learning. Applied Language Learning, 5(2), 31-56.

Prihatin, P. N. (2012). The Computer integration into the EFL Instruction in Indonesia: An Analysis of Two Universty Instructors in Integration Computer Technology into EFL Instruction to Encourage Students' Language Learning Engagement. Doctoral Thesis. School of Education. Loyola University of Chicago. Chicago.

Pusack, J. P., \& Otto, S. (1997). Taking control of multimedia. In M. D. Bush \& R. M. Terry (Eds.), Technology-enhanced language learning (pp. 1-46). Lincolnwood, IL: National Textbook Company.

Sharma, P., \& Barrett, B. (2007). Blended learning: Using technology in and beyond the language classroom. Oxford: Macmillan Publishers

Urtel, M. G. (2008). Assessing academic performance between traditional and distance education course formats. Educational Technology \& Society, 11(1), 322-330. 
Wilcox, B. L., \& Wojnar, L. C. (2000). Best practice goes online. Reading online, 4(2), Retrieved October 1, 2012, from http://www.readingonline.org/ articles/wilcox/ 